\title{
Efficacy of Newer Molecules of Insecticides against Gram Pod Borer, Helicoverpa armigera (Hub.) on Chickpea
}

\author{
Savita P. Adsure ${ }^{1}$, Pandurang B. Mohite ${ }^{2}$
}

\begin{abstract}
Field study was conducted to determine the efficacy of Clothianidin 50 WDG, Indoxacarb, Flubendiamide 480 SC, Fipronil 5 SC, Spinosad 45 SC, Indoxacarb 14.5 SC, Rynaxypyr 20 SC, Chorpyriphos 20 EC against the surviving larval population of gram pod borer, Helicoverpa armigera (Hub.) on chickpea in the experimental research area of farmers field in Chandre village, Dist-Kolhapur during Rabi season 2009-10. In newer insecticides lowest number of surviving population of larvae was recorded in treatment Rynaxypyr 20 SC @ $40 \mathrm{~g}$ a.i./ha 0.70 larvae/plant, highest yield recorded 15.00q/ha band lower pod damage recorded 8.10 per cent.
\end{abstract}

Keywords: Helicoverpa armigera, Clothianidin 50 WDG, Indoxacarb, Flubendiamide 480 SC, Fipronil 5 SC, Spinosad 45 SC, Indoxacarb 14.5 SC, Rynaxypyr 20 SC,

\section{Introduction}

Chickpea, Cicer arientinum Linn. is constitutes as world's third most important pulse crop and India contributes 80 per cent of the total world's production. Due to its richness in proteins and amino acids, it plays vital role in vegetarian diet. Southern and central part of India one of the major constrains for lower yield of crop is the damage caused by the pod borer, Helicoverpa armigera (Hub.) right from vegetative to podding stage. A number of chemical insecticides have been reported to be effective in chickpea (Khurana, 1996 and Dhingara et al.2003). Most of the insecticides belonging to organophosphates, carbamates and synthetic pyrethroids etc. Their indiscriminate use has created number of well known problems. Hence there is a need to use never insecticides which are selective and are effective at lower doses against pod borer in chickpea.

\section{Material and Methods}

The experiments was laid out in randomised block design with eight treatments (Table 1) including control and replicated thrice in $4.2 \times 3.60 \mathrm{M}^{2}$ plot size during 20092010 at farmer's field in Chandre village in Tal Radhanagari, Dist-Kolhapur. The chickpea variety Digvijay was raised as per the recommended package of practices exept plant protection measures. The required quantity of spray solution was calibrated by spraying the control plot with water. Spray fluid were prepared by adding required quantity of pesticide. Spraying was undertaken in the evening hours (4.30 to 5.30 p.m.) using hand compression sprayer.

\section{Observations}

\section{A. Assessment of Larval Population}

Five plants per plot were selected randomly and were tagged for recording observations. The pre count and post larval count were recorded a day before treatment and three, seven, and ten days after the application of the treatment. Efficacy of different fungi at different concentration were calculated on the basis of surviving larval populations per plant after the treatment. The data on surviving larval population of larvae were subjected to square root transformation $(\sqrt{x+0.5})$ and then subjected to statistical analysis. At harvest, the observations on damaged healthy pod and yield were recorded and the per cent pod damage was calculated.

\section{B. Assessment of Pod Damage and Yield}

Pod damage

Pod damage was taken at the time of harvesting, total number of pods and number of damaged pods was taken and per cent pod damage was worked by using following formula.

Percent Pod damage $=$ Number of affected pods $/$ plants X 100 TotalNumber of pods/plants

\section{Yield}

The yield obtained in individual treatment of chickpea crop was recorded separately for assessing the efficacy of different treatments. Data of yield $\mathrm{Kg} /$ plot was converted into $\mathrm{q} \mathrm{ha}^{-1}$ and it was subjected to analysis of variance.

\section{Results and Discussion}

The effect of various treatments under investigation on the $H$. armigera are presented in Table 1. Pretreatment larval population of $H$. armigera was nonsignificant indicating uniform larval population but larval population differed significantly among the treatments after the application of insecticides (Table 1). A sharp decline in the surviving population density of $H$. armigera was noted third day after the application of each spray compared to control. Minimum surviving population of gram pod borer was observed on seven day after the application of each spray. In newer insecticides lowest number of surviving population of larvae was recorded in treatment rynaxypyr 20 SC @ $40 \mathrm{~g}$ a.i./ha 0.70 larvae/plant which was at par with treatment flubendiamide 480 SC @ 48 g a.i./ha 0.90 larvae/plant. The treatment with clothianidin, spinosad and indoxacarb were next in orders of efficacy at seven days after second spray.

In present investigation highest yield recorded in the treatment with rynaxipyr $20 \mathrm{SC} @ 40 \mathrm{~g}$ a.i./ha $15.00 \mathrm{q} / \mathrm{ha}$ and lowest pod damage recorded ( 8.10 per cent), followed

\section{Volume 4 Issue 12, December 2015}




\section{International Journal of Science and Research (IJSR) \\ ISSN (Online): 2319-7064}

Index Copernicus Value (2013): 6.14 | Impact Factor (2014): 5.611

by high yield recorded in treatment flubendiamide $480 \mathrm{SC}$ (a) $48 \mathrm{~g}$ a.i./ha $14.40 \mathrm{q} / \mathrm{ha}$ and pod damage recorded 9.00 per cent, clothianidin, spinosad and indoxacarb was at par with each other. The lowest yield was recorded in untreated control $6.00 \mathrm{q} / \mathrm{ha}$.

Moreover, the studies of Chowdary et al. (2010) and Babariya et al. (2010) were also in close conformity with the results of present study indicating that Rynaxypyr was the most effective insecticide. Rynaxypyr established itself as the most effective insecticide with respect to grain yield $15.00 \mathrm{q} / \mathrm{ha}$ and recorded lowest pod damage 8.10 per cent, followed by flubendiamide, clothianidin, spinosad and indoxacarb (Table 1). These finding are in general agreement with those of Zahid Ali Shan et al. (2003), Sidde Gowda et al. (2007) and Ashok Kumar and Shivaraju (2009) where they reported that the application of insecticides reduced the larval population of $H$. armigera to considerable extent and hence increased the yield.

In past, the best insecticide was reported to be the chlorpyriphos (Balasubramanian et al. 2001, Zahid Ali Shan et al. 2003, Sidde Gowda et al. 2007, but in the present study rynaxypyr (coragen) proved to be the best insecticide. Control of this pest was not adequate now probably due to in part to the development of insecticide resistance because of frequent use of insecticides. Rynaxypyr (corogen) was proved to be the best insecticides against the pest. However, other insecticides may also remain fully effective against $H$. armigera if used according to manufacturer's recommendations (Sharma and Chawla, 1992).

\section{References}

[1] Ashok Kumar, C. T. and C. Shivaraju, 2009. Evaluation of newer insecticide molecules against pod borers of black gram. Karnataka J. Agric. Sci., 22 : 521-523.

[2] Babariya, P.M., B.B. Kabaria, V.N. Patel and M.D. Joshi, 2010. Chemical control of gram pod borer, Helicoverpa armigera (Hub.) infesting pigeonpea. Legume Res. 33 (3) : 224-226.

[3] Balasubramanian, G., P. C. S. Babu and T. R. Manjula, 2001. Efficacy of Spicturin against Helicoverpa armigera (Hub.) on chickpea (Cicer arietinum L.) Madras Agric. J.,88 : 336-8.

[4] Chowdary, L.R., M. Bheemanna and L. Ranjith Kumar, 2010. Bioefficacy of rynaxypyr (corogen) 20 SC against fruit borer Helicoverpa armigera (Hubner.) in okra. International J. of Plant Prot. 3 (2) : 379-381.

[5] Dhingara, S., Kodandaram, M.H.Hedge, R.S. and Srivastava, C. 2003. Evaluation of different insecticides mixture against third instars larvae of Helicoverpa armigera Hub. Annals of plant protection science $11: 274-276$.

[6] Khurana, A. D. 1996. Efficacy of some insecticides against pod borer, Helicoverpa armigera Hub. on chick pea. Journal of Insect science. 9:191-192.

[7] Sharma, R. K. and R. P. Chawla, 1992. Residues of cypermethrin in chickpea crop. J. Insect Sci. 5 :103-104.

[8] Sidde Gowda, D. K., B. V. Patil and S. Yelshetty, 2007. Field evaluation of comparative efficacy of dusts and emulsifiable concentration formulations against gram pod borer in chickpea ecosystem. Karnataka J. Agric. Sci., 20 (2) : 276-278.

[9] Zahid Ali Shah, M. K. Shahzad and M. A. Sharaz, (2003). Efficacy of different insecticides against larval population density of gram pod borer, Helicoverpa armigera (Hub.) with reference to chickpea in Faisalabad- Pakistan. International J. of Agric. And Biology. 05 (3) : 326-328.

Table 1: Efficacy of newer insecticides against larvae of Helicoverpa armigera under field conditions

\begin{tabular}{|c|c|c|c|c|c|c|c|c|c|}
\hline $\begin{array}{l}\text { Sr. } \\
\text { No }\end{array}$ & Treatments & $\begin{array}{c}\text { Dose } \\
\left(\mathrm{gm} \mathrm{a.i.}^{-1} \mathrm{ha}^{-1}\right)\end{array}$ & $\begin{array}{c}\text { Pre } \\
\text { Count }\end{array}$ & \multicolumn{6}{|c|}{$\begin{array}{c}\text { Surviving Larval } \\
\text { Population per plant }\end{array}$} \\
\hline & & & & \multicolumn{3}{|c|}{ First Spraying } & \multicolumn{3}{|c|}{ Second Spraying } \\
\hline & & & & 3DAT & $7 \mathrm{DAT}$ & 10DAT & 3DAT & 7DAT & 10DAT \\
\hline 1 & $\begin{array}{l}\text { Clothianidin } \\
50 \text { WDG }\end{array}$ & 250 & $\begin{array}{c}8.66 \\
(17.05)\end{array}$ & $\begin{array}{l}2.75 \\
(1.80)\end{array}$ & $\begin{array}{c}2.40 \\
(1.70)\end{array}$ & $\begin{array}{c}2.40 \\
(1.70)\end{array}$ & $\begin{array}{l}2.10 \\
(1.61)\end{array}$ & $\begin{array}{c}1.80 \\
(1.51)\end{array}$ & $\begin{array}{c}1.90 \\
(1.54)\end{array}$ \\
\hline 2 & $\begin{array}{l}\text { Flubendiamide } \\
480 \mathrm{SC}\end{array}$ & 48 & $\begin{array}{c}8.33 \\
(16.74)\end{array}$ & $\begin{array}{l}2.20 \\
(1.64)\end{array}$ & $\begin{array}{c}1.90 \\
(1.54)\end{array}$ & $\begin{array}{c}2.10 \\
(1.61)\end{array}$ & $\begin{array}{l}1.30 \\
(1.34)\end{array}$ & $\begin{array}{c}0.90 \\
(1.18)\end{array}$ & $\begin{array}{l}1.10 \\
(1.26)\end{array}$ \\
\hline 3 & $\begin{array}{c}\text { Fipronil } \\
5 \mathrm{SC} \\
\end{array}$ & 30 & $\begin{array}{c}9.85 \\
(18.24) \\
\end{array}$ & $\begin{array}{c}4.10 \\
(2.14) \\
\end{array}$ & $\begin{array}{c}3.40 \\
(1.97) \\
\end{array}$ & $\begin{array}{c}3.80 \\
(2.07) \\
\end{array}$ & $\begin{array}{c}3.50 \\
(2.00) \\
\end{array}$ & $\begin{array}{c}2.86 \\
(1.83) \\
\end{array}$ & $\begin{array}{c}3.10 \\
(1.89)\end{array}$ \\
\hline 4 & $\begin{array}{c}\text { Spinosad } \\
45 \mathrm{SC}\end{array}$ & 84.37 & $\begin{array}{c}9.29 \\
(17.66)\end{array}$ & $\begin{array}{l}2.90 \\
(1.84)\end{array}$ & $\begin{array}{c}2.60 \\
(1.76)\end{array}$ & $\begin{array}{c}2.70 \\
(1.78)\end{array}$ & $\begin{array}{c}2.35 \\
(1.68)\end{array}$ & $\begin{array}{c}1.90 \\
(1.54)\end{array}$ & $\begin{array}{c}2.10 \\
(1.61)\end{array}$ \\
\hline 5 & $\begin{array}{c}\text { Indoxacarb } \\
14.5 \mathrm{SC} \\
\end{array}$ & 60 & $\begin{array}{c}6.66 \\
(14.89) \\
\end{array}$ & $\begin{array}{c}3.10 \\
(1.89)\end{array}$ & $\begin{array}{c}2.70 \\
(1.78) \\
\end{array}$ & $\begin{array}{c}3.00 \\
(1.87) \\
\end{array}$ & $\begin{array}{c}2.60 \\
(1.76)\end{array}$ & $\begin{array}{c}2.20 \\
(1.64) \\
\end{array}$ & $\begin{array}{c}2.40 \\
(1.37)\end{array}$ \\
\hline 6 & $\begin{array}{c}\text { Rynaxypyr } \\
20 \text { SC }\end{array}$ & 40 & $\begin{array}{c}9.46 \\
(17.85)\end{array}$ & $\begin{array}{l}2.10 \\
(1.61)\end{array}$ & $\begin{array}{c}1.80 \\
(1.51)\end{array}$ & $\begin{array}{c}1.90 \\
(1.54)\end{array}$ & $\begin{array}{l}1.10 \\
(1.26)\end{array}$ & $\begin{array}{c}0.70 \\
(1.09)\end{array}$ & $\begin{array}{c}0.90 \\
(1.18)\end{array}$ \\
\hline 7 & $\begin{array}{c}\text { Choropyriphos } \\
20 \text { EC }\end{array}$ & 250 & $\begin{array}{c}7.33 \\
(15.68) \\
\end{array}$ & $\begin{array}{c}4.50 \\
(2.23)\end{array}$ & $\begin{array}{c}3.80 \\
(2.07)\end{array}$ & $\begin{array}{c}4.10 \\
(2.14)\end{array}$ & $\begin{array}{c}4.40 \\
(2.21)\end{array}$ & $\begin{array}{c}3.10 \\
(1.89)\end{array}$ & $\begin{array}{c}3.50 \\
(2.00)\end{array}$ \\
\hline 8 & Control & & $\begin{array}{c}10.22 \\
(18.63)\end{array}$ & $\begin{array}{l}8.10 \\
(2.93)\end{array}$ & $\begin{array}{c}8.90 \\
(3.06)\end{array}$ & $\begin{array}{c}9.50 \\
(3.16)\end{array}$ & $\begin{array}{l}10.20 \\
(3.27)\end{array}$ & $\begin{array}{l}12.10 \\
(3.54)\end{array}$ & $\begin{array}{c}13.5 \\
(3.74)\end{array}$ \\
\hline & $\mathrm{SE} \pm$ & & NS & 0.08 & 0.06 & 0.09 & 0.12 & 0.11 & 0.09 \\
\hline & $\mathrm{CD}$ at $5 \%$ & & NS & 0.20 & 0.14 & 0.20 & 0.26 & 0.25 & 0.21 \\
\hline
\end{tabular}

Figures in parentheses denote $\sqrt{x+0.5}$ transformed values 


\section{International Journal of Science and Research (IJSR) \\ ISSN (Online): 2319-7064}

Index Copernicus Value (2013): 6.14 | Impact Factor (2014): 5.611

Table 2: Efficacy of entomopathogenic fungi on pod damage and yield of chickpea

\begin{tabular}{|c|c|c|c|c|}
\hline S. No. & Treatment & $\begin{array}{c}\text { Concentration } \\
\left(\text { Conidia }^{-1}\right)\end{array}$ & $\begin{array}{c}\text { \%Pod damage due to } \\
\text { Helicoverpa armigera }\end{array}$ & Yield q/ha \\
\hline 1. & M. anisopliae & $1 \times 10^{9}$ & $\begin{array}{c}11.83 \\
(20.09)\end{array}$ & 13.00 \\
\hline 2. & M. anisopliae & $1 \times 10^{10}$ & $\begin{array}{c}9.50 \\
(17.95)\end{array}$ & 14.50 \\
\hline 3. & B. bassiana & $1 \times 10^{9}$ & $\begin{array}{c}17.16 \\
(24.43)\end{array}$ & 10.00 \\
\hline 4. & B. bassiana & $1 \times 10^{10}$ & 14.16 & 12.50 \\
\hline 5. & N.rileyi & $1 \times 10^{9}$ & 19.50 & 9.76 \\
\hline 6. & N.rileyi & $1 \times 10^{10}$ & $\begin{array}{c}10.06 \\
(23.58)\end{array}$ & 10.16 \\
\hline 7. & Control & & 27.50 & 5.90 \\
\hline & SE \pm & & 0.86 & 0.49 \\
\hline & CD at $5 \%$ & & 1.88 & 1.08 \\
\hline
\end{tabular}

Figures in parenthesis are arcsin values. 